\title{
Gray Whale Calls Recorded near Barrow, Alaska, throughout the Winter of 2003-04
}

\author{
K.M. STAFFORD, ${ }^{1}$ S.E. MOORE, ${ }^{2}$ M. SPILLANE ${ }^{3}$ and S. WIGGINS ${ }^{4}$
}

(Received 4 July 2006; accepted in revised form 11 January 2007)

\begin{abstract}
Since the mid-1990s, gray whales (Eschrichtius robustus) have been reported with increasing frequency near Barrow, Alaska, during summer and autumn months. In collaboration with a broad-scale oceanographic study, three autonomous acoustic recorders were moored northeast of Barrow in October 2003 to provide capability for year-round detection of calls. Two recorders were recovered in September 2004, one from the continental slope (water depth $=316 \mathrm{~m}$ ) and one from near the base of the slope (water depth $=1258 \mathrm{~m}$ ). The shallow instrument recorded for roughly 3 months ( 87 days), and the deeper instrument for roughly 7.3 months (222 days). Gray whale calls were recorded on both instruments throughout their periods of operation. The calling rate at the shallower instrument was higher than at the deeper recorder, but surprisingly, the deeper instrument detected calls throughout the 2003-04 winter, though the calling rate diminished as winter progressed. Low-frequency N1/S1 pulses, the most common of the calls produced by gray whales, were recorded from deployment through December 2003 on the shallower of the two instruments and from deployment through May 2004 on the deeper instrument. Because this is the first-ever winterlong acoustic study, we cannot be certain that gray whales have not overwintered in the Beaufort Sea in the past. However, a combination of increasing population size and habitat alteration associated with sea ice reduction and warming in the Alaskan Arctic may be responsible for the extra-seasonal gray whale occurrence near Barrow.
\end{abstract}

Key words: gray whale, Eschrichtius robustus, acoustics, Barrow

RÉSUMÉ. Depuis le milieu des années 1990, des baleines grises (Eschrichtius robustus) ont été signalées de plus en plus souvent près de Barrow, en Alaska, pendant les mois d'été et d'automne. En collaboration avec une étude océanographique à grande échelle, trois enregistreurs acoustiques autonomes ont été amarrés au nord-est de Barrow en octobre 2003 afin de pouvoir détecter les cris de baleine à l' année. Deux enregistreurs ont été récupérés en septembre 2004, un de la pente continentale (à une profondeur d'eau de $316 \mathrm{~m}$ ) et l'autre près de la base de la pente (à une profondeur de $1258 \mathrm{~m}$ ). L'instrument le moins profond a enregistré les sons pendant trois mois environ ( 87 jours), tandis que l'instrument le plus profond a enregistré les sons pendant environ 7,3 mois (222 jours). Les cris de baleines grises ont été enregistrés au moyen des deux instruments. Le nombre de cris enregistrés à l'aide de l'instrument le moins profond était plus élevé qu'avec l'instrument le plus profond. Cependant, et fait étonnant, l'instrument le plus profond a détecté des cris pendant l'hiver 2003-2004, bien que le nombre de cris ait diminué au fur et à mesure que l'hiver avançait. Les ondes pulsées de basse fréquence N1/S1, soit les cris les plus courants produits par les baleines grises, ont été enregistrées à partir de l'installation de l'instrument le moins profond en décembre en 2003 et de l'installation de l'instrument le plus profond jusqu'au mois de mai 2004. Puisqu'il s'agit de la première étude acoustique ayant duré pendant tout l'hiver, nous ne pouvons pas savoir avec certitude si les baleines grises n'ont pas hiverné dans la mer de Beaufort par le passé. Toutefois, l'augmentation de la population de baleines, alliée à la modification de l'habitat, à la diminution de la glace de mer et au réchauffement qui sévit dans la région arctique de l'Alaska, pourrait être responsable de la présence de baleines grises hors saison près de Barrow.

Mots clés : baleine grise, Eschrichtius robustus, étude acoustique, Barrow

Traduit pour la revue Arctic par Nicole Giguère.

Two decades ago, gray whales were rare visitors to the Beaufort Sea (Rugh and Fraker, 1981). Since the mid 1990s, tens to hundreds of gray whales have been reported between Barrow and Harrison Bay in the Alaskan Beaufort Sea in summer and through early autumn (J.C. George, pers. comm. 2005). Meanwhile, bowhead whales (Balaena mysticetus) have also been seen northeast and southwest of Barrow: small groups of 10 or fewer whales were spotted during aerial surveys in July 1999, 2003, and 2005 (S.E. Moore, unpubl. data). The apparent increase in sightings of both species could be due to expanding populations (George et al., 2004; Rugh et al., 2005), climate-induced changes in habitat (e.g., Moore et al., 2003), or both.

Oceanographic research related to climate change is expanding in the Arctic, which provides opportunities for collaborative investigations of cetacean habitats. One such

\footnotetext{
${ }^{1}$ APL-University of Washington, 1013 NE 40th Street, Seattle, Washington 98105, USA; Stafford@ apl.washington.edu

${ }^{2}$ NOAA/AFSC, Applied Physics Laboratory, University of Washington, Seattle, Washington 98015, USA; sue.moore@noaa.gov

${ }^{3}$ Lakeside School, Seattle, Washington 98125, USA; spillan3@u.washington.edu

${ }^{4}$ University of California, San Diego, Scripps Institution of Oceanography, San Diego, California 92093, USA; swiggins@ucsd.edu

(C) The Arctic Institute of North America
} 


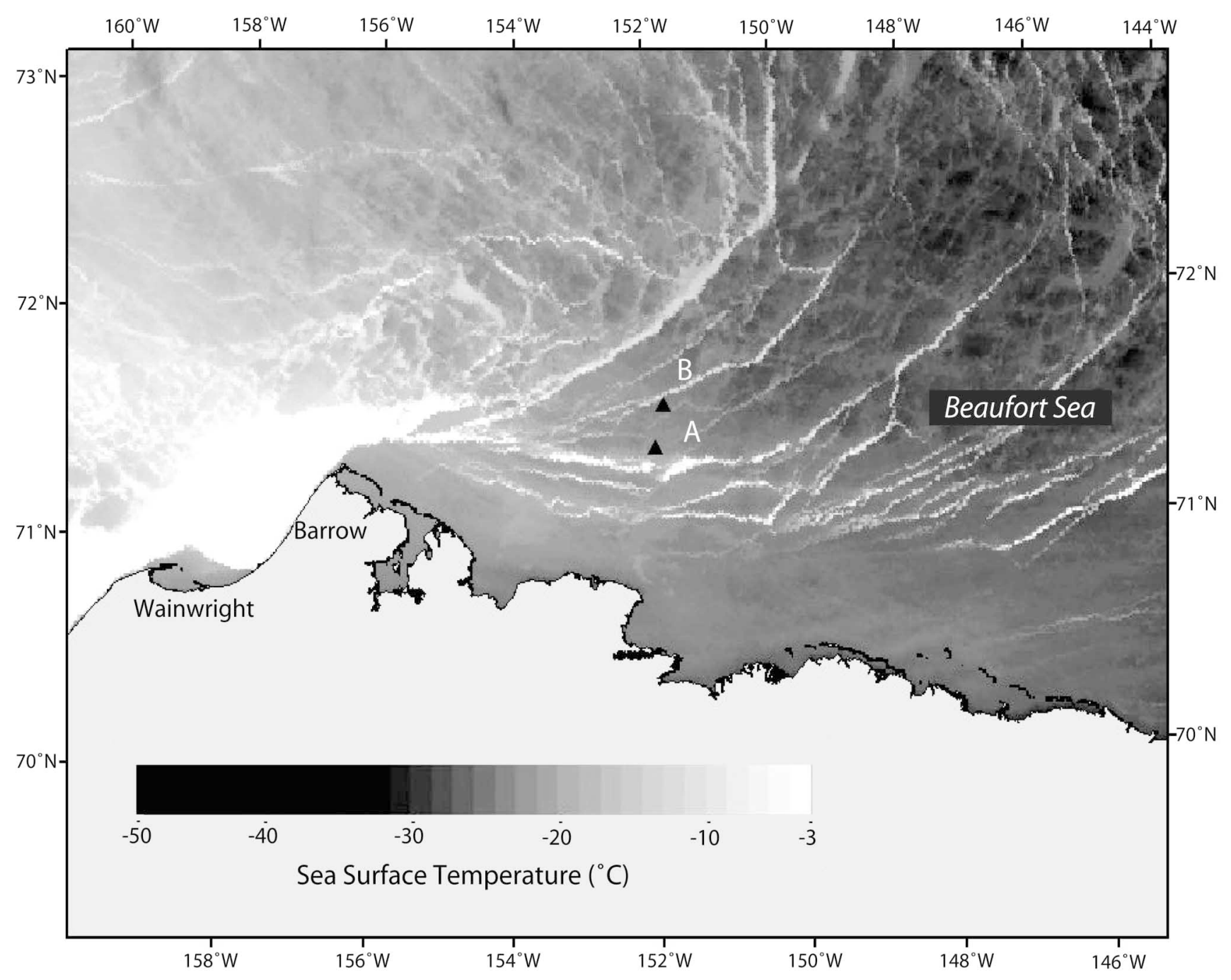

FIG. 1. Locations of the ARPs ( $\mathbf{\Delta})$ in the Beaufort Sea, overlain on an AVHRR sea ice scene from 25 January 2004 that shows the existence of leads in the vicinity of the hydrophones. The scale indicates the sea surface temperature in ${ }^{\circ} \mathrm{C}$, derived from AVHRR. Instruments A and B were deployed in early October 2003 and recovered in September 2004. The ARP at site A recorded for 87 days (4 October to 29 December 2003), and the one at site B, for 222 days (3 October 2003 to 12 May 2004).

collaboration with the Western Arctic Shelf-Basin Interactions (SBI) Project (http://sbi.utk.edu), sponsored by the U.S. National Science Foundation and the Office of Naval Research, resulted in successful yearlong deployment of two autonomous acoustic recording packages (ARPs, Wiggins, 2003) in the western Beaufort Sea to provide continuous sampling of whale calls.

Three ARPs were deployed in early October 2003 near a mooring line designed for fine-scale sampling of physical oceanographic parameters along the Beaufort Sea slope. Two ARPs were recovered in September 2004 (Fig. 1: A and B); however, the third instrument failed to return to the surface upon command. Instrument A was deployed at $71^{\circ} 28.3^{\prime} \mathrm{N}, 151^{\circ} 56^{\prime} \mathrm{W}$ in water $316 \mathrm{~m}$ deep, and instrument $\mathrm{B}$ was deployed at $71^{\circ} 39.3^{\prime} \mathrm{N}, 151^{\circ} 48^{\prime} \mathrm{W}$ in water $1258 \mathrm{~m}$ deep. The recorders are designed to sit on the sea floor, with a hydrophone suspended roughly $10 \mathrm{~m}$ above the instrument by flotation. Flexible polyethylene rings decouple the hydrophone from a support line and suppress the noise made by strumming on the line (Wiggins, 2003).
Acoustic data were recorded continuously at $1 \mathrm{kHz}$ sampling rate and low-pass filtered with a six-pole filter at the Nyquist frequency, for an effective bandwidth of 10-500 $\mathrm{Hz}$ (see Wiggins, 2003). Although gray whale calls range in frequency from roughly 20 to $2000 \mathrm{~Hz}$, most calls contain significant energy below $500 \mathrm{~Hz}$ (Dahlheim et al., 1984; Moore and Ljungblad, 1984), well within the sampled bandwidth.

Upon recovery of the instruments, the internal hard drives were removed and the data were downloaded for processing. Instrument B recorded for 222 days, from 3 October 2003 until 12 May 2004. Unfortunately, instrument A had a battery malfunction, so it recorded data for only 87 days, from 4 October 2003 to 29 December 2003. The available data files were split into 10-minute segments to facilitate processing, and $20 \mathrm{~s}$ spectrogram equalization was applied to remove long-term noise. Data were analyzed using ISHMAEL (Integrated System for Holistic Multichannel Acoustic Exploration and Localization) and Raven software (Mellinger, 2002; Charif et al., 2004). Data files 


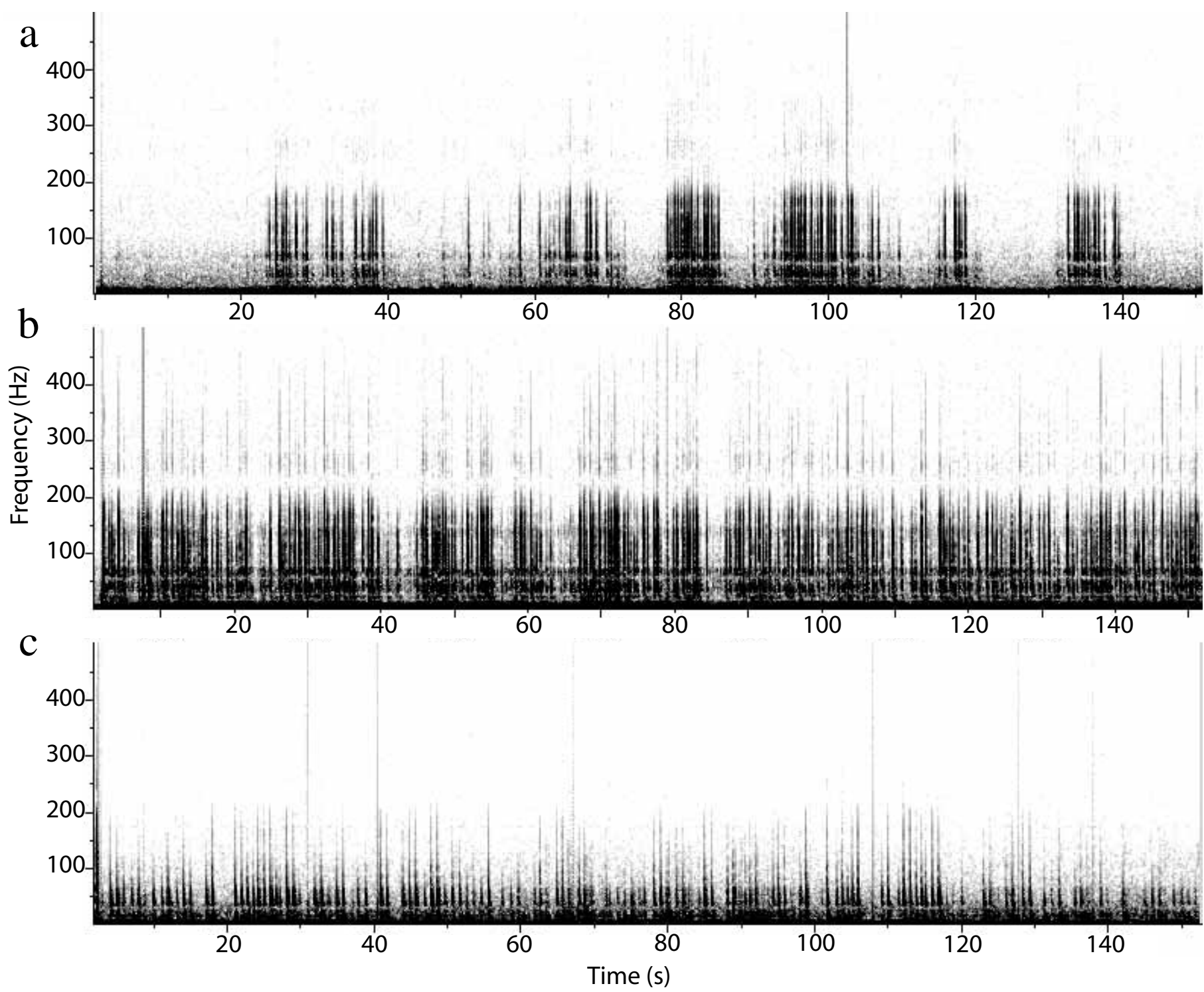

FIG. 2. Gray whale N1/S1 pulses. a) Discrete series of pulses, probably produced by one animal, recorded at site A on 28 October 2003; b) pulses from multiple animals recorded at site A on 7 November 2003; c) pulses recorded at site B on 29 January 2004 (256 point FFT, 75\% overlap, Hanning window).

were scanned visually for the presence of calls from gray whales. Time and frequency measurements were made for gray whale calls from both instruments $(256$ point Fast Fourier Transform [FFT], 75\% overlap, Hanning window). Results reported here are based on analysis of data recorded over 211 calendar days by the two ARPs: a combined total of 309 days of acoustic data. Other sounds recorded during this time include noise from ships and sea ice and the calls of bowhead whales. Our sample rate was too low to allow reliable identification of calls from seals, walrus, or belugas.

The low-frequency pulses of gray whales (S1 from Dahlheim et al., 1984 and N1 from Moore and Ljungblad, 1984) were by far the most common sound recorded on both ARPs. These calls are the most common type produced by gray whales. They are distinctive because of their aural characteristics (pitch and duration) and because they are emitted in series, called "bursts" or "bouts." Other call types attributed to gray whales may have been recorded, but we focused only on the low-frequency pulses.

Over 1500 individual pulses from 202 calling bouts were measured. On average, the low frequency was $35.8 \pm$ $11.8 \mathrm{~Hz}$ (range 13-71 Hz), the high frequency was 149.5 \pm 42.8 (range 59-258 Hz), and pulse duration was $0.4+$ $0.1 \mathrm{~s}$. Mean bandwidth was $113.7 \pm 39.0 \mathrm{~Hz}(\mathrm{n}=1511)$. The interpulse interval (time from the end of one pulse to the beginning of the next in a bout) was $0.9 \pm 0.8 \mathrm{~s}(\mathrm{n}=$ 1300), while the interbout interval ranged from 5 to $1524 \mathrm{~s}$ (mean $101 \mathrm{~s} ; \mathrm{n}=185$ ). Gray whale pulses (Fig. 2) were first recorded at site A on 6 October 2003 and continued regularly every week until the end of recording on 29 December (Fig. 3). Gray whale pulses were the dominant sound at site A, often appearing on spectrograms as black smears from around 50 to $150 \mathrm{~Hz}$ (Fig. 2b). Although we do not know how many animals were producing pulses, many thousands of pulses were recorded during the 2.5 


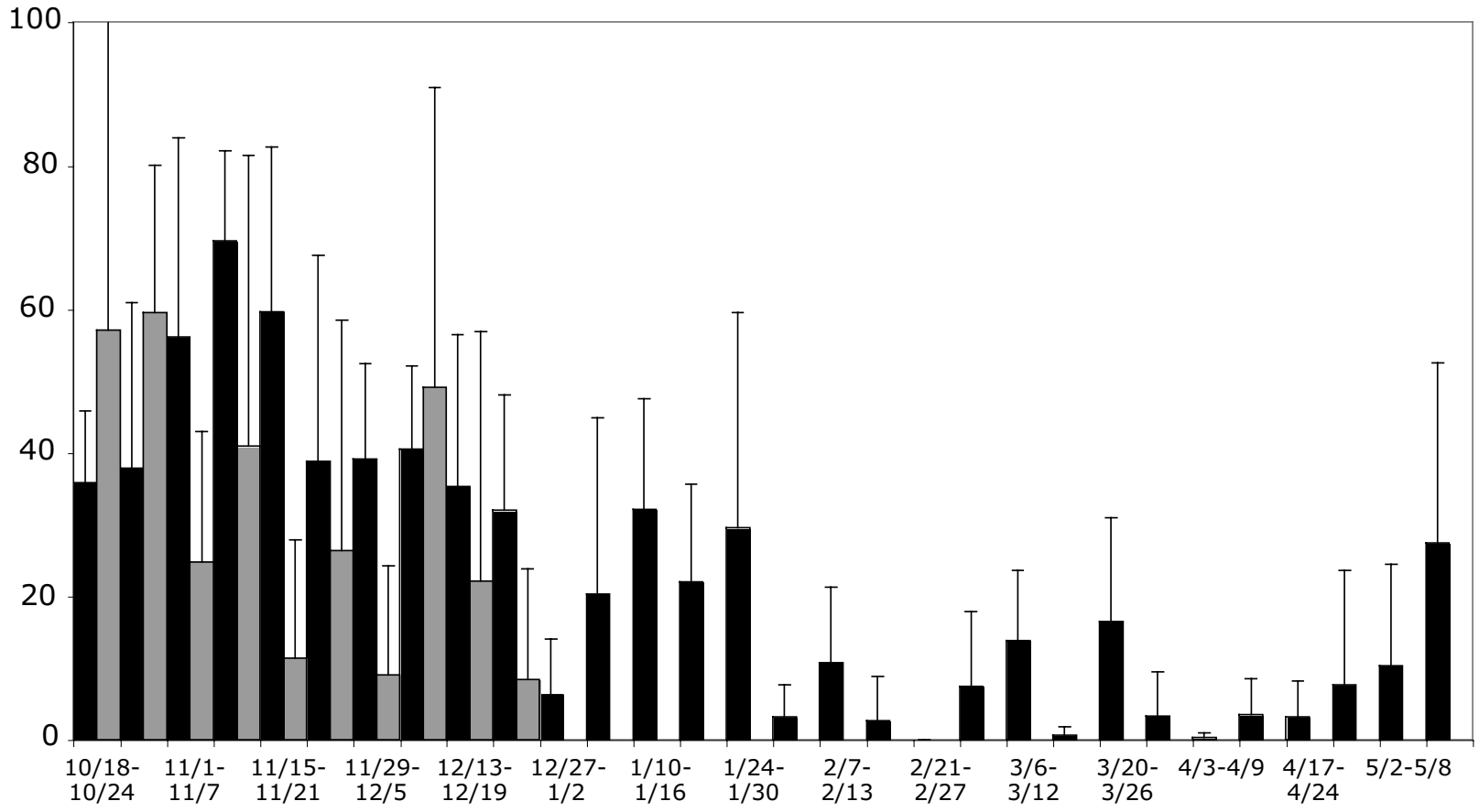

Date by week (2003-2004)

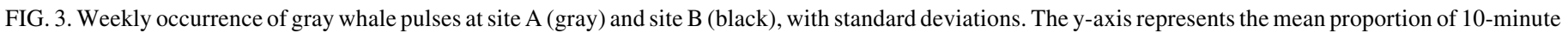

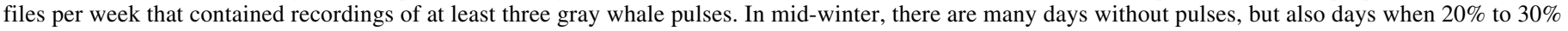
of the sound files contained pulses.

months when gray whales were recorded on site A. About $30 \%$ of the 10 -minute files contained gray whale pulses, although the proportion of gray whale pulses in individual 10-minute files was quite variable, ranging from 0 to $100 \%$ of the sounds recorded (Fig. 3). Because this hydrophone failed earlier than expected, no seasonal calling pattern was evident.

Gray whale pulses were also recorded very regularly at site B. Pulses were first recorded on 6 October, with peak calling indices from November to January and detections continuing until 12 May 2004, the end of the acoustic record (Fig. 3). While still quite loud and clear (Fig. 2c), gray whale pulses were much less common in the late winter months (February to April), suggesting that fewer animals were producing sounds at that time.

Overall, more gray whale pulses were recorded at site A than at site B, which may reflect patterns of prey availability across the continental slope in the western Beaufort Sea. Gray whales are opportunistic foragers that feed on neritic, epibenthic, and benthic infauna (e.g., Nerini, 1984; Kim and Oliver, 1989; Dunham and Duffus, 2001). Although gray whales were commonly seen feeding on benthic amphipods (Ampeliscidae) in the northern Bering Sea during the 1980s (Moore et al., 2000), a dearth of whales feeding there in 2002 (Moore et al., 2003) and recent reports of whales feeding year-round on epibenthic cumaceans (Diastylidae) offshore near Kodiak (Moore et al., 2007) suggest that gray whales may be altering their foraging habits offshore Alaska. We do not know what gray whales feed on northeast of Barrow, but epibenthic mysid swarms and surface slicks of euphausiids, either of which would be suitable prey, have been reported for these waters. During aerial surveys conducted in late August and early September 2005, gray whales (17 sightings of 35 whales) that appeared to be feeding were clustered along the shelf break roughly $40 \mathrm{~km}$ northeast of Barrow and about $100 \mathrm{~km}$ from site B (S.E. Moore, unpubl. data). We do not suggest that the calls reported here, especially in winter, are from feeding whales near Barrow-only that gray whales seem to find sufficient forage along the continental slope in the western Beaufort Sea at least during some part of the year.

We had assumed that the wide extent and great thickness of sea ice in the western Beaufort Sea would exclude gray whales from this area in winter. Indeed, in October 1988 the entrapment of three juvenile gray whales in sea ice near Point Barrow resulted in an international effort to rescue the whales from the ice (Anonymous, 1989). Thus, it is possible but quite unlikely that the gray whale calls we detected in winter came from ice-entrapped animals. To determine if enough open water was available for whales during winter months, we examined Advanced Very High Resolution Radiometer (AVHRR) images provided by the Geophysical Institute of the University of Alaska Fairbanks. These images show sufficient space in leads where gray whales might surface to breathe (Fig. 1). Further, the open water fraction throughout the winter 2003-04 ice season was one of the highest recorded in data collected since 1993 (Eicken et al., 2006). We are therefore confident that the gray whale(s) we recorded were not trapped. 
The most unexpected result of this study was the detection of gray whale calls throughout the winter. Generally, it is believed that gray whales depart the Chukchi Sea and migrate south through the Bering Strait sometime between early October and mid or late December (Braham, 1984; Moore et al., 2000; Rugh et al., 2001). The timing of the southbound migration has been studied in relation to a research station in central California, where the official census of gray whales is conducted (Rugh et al., 2005). Rugh et al. (2001) showed that the southbound migration proceeds in a predictable order, but median dates shifted by roughly one week to a later date after the 1977-78 oceanographic regime shift in the North Pacific. This shift suggests that gray whales are spending more time in Subarctic and Arctic seas. Rugh et al. (2001) proposed several hypotheses for the delay in the migration: first, that the increase in population has caused a northward expansion of the whales' range; second, that along with population growth comes increased competition for food, both during the summer and along the migratory corridor; and lastly, that ocean climate changes such as the $\sim 1977$ regime shift or global warming have changed sea-ice patterns so that foraging habitat in the Arctic is available to gray whales for longer periods of time. Whatever the reason, Perryman et al. (2002) reported that years when the feeding area north of St. Lawrence Island (Chirikov Basin) remained ice-free were positively correlated with whale calf production. Further, Moore et al. (2003) proposed that hydrographic or climate-induced changes in the Chirikov Basin associated with decreased prey availability may result in spatial and temporal expansion of gray whale foraging habitat. A combination of these factors (increasing population and habitat alteration associated with ocean climate changes) may be responsible for the extra-seasonal gray whale occurrence near Barrow reported here. Clearly, we need further long-term acoustic monitoring in conjunction with prey sampling and studies of population dynamics and body condition (e.g., Perryman and Lynn, 2002) to better understand the significance of these observations.

This study demonstrates that passive acoustic monitoring is useful for detecting whales during periods of darkness and in ice conditions that preclude visual observations. The efficacy of acoustic detection of whales in the Alaskan Arctic has been demonstrated in past shorter-term studies near Barrow, which included the use of sonobuoys during aerial surveys in autumn (Moore et al., 1989) and acoustic arrays to locate bowhead whales during their spring migration past Barrow (Clark and Ellison, 2000). Indeed, the successful integration of acoustic data with visual observations to census bowhead whales has been the exemplar for monitoring large whale populations with passive acoustics (cf. Ko et al., 1986; Clark and Ellison, 2000).

The data presented here represent the first all-winter study of the calls of gray whales in the Beaufort Sea and illustrate the value of year-round acoustic monitoring for Arctic cetaceans. We propose that autonomous acoustic monitoring become a standard practice. Because such monitoring is new, it has the potential to provide surprising discoveries of acoustically active Arctic species, as well as documenting changes in seasonal trends and occurrence for migrant species during this period of extreme ocean climate variability.

\section{ACKNOWLEDGEMENTS}

We are grateful to R. Pickart of the Woods Hole Oceanographic Institution (WHOI) and R. Woodgate of the University of Washington who generously allowed us to deploy and retrieve the instruments during their NSF-SBI scheduled cruises. L. Munger of the Scripps Institution of Oceanography (SIO) deployed the recorders, and J. Kemp (WHOI) recovered them. H. Eicken and P. Cotter (University of Alaska Fairbanks) provided sea ice image data produced under a contract with the Minerals Management Service and generously shared their work on the fraction of open water off Barrow in the winter. We thank D. Rugh and M. Dahlheim for comments that improved an earlier version of this manuscript. S. Blackwell, W.J. Richardson, and an anonymous reviewer greatly improved the final version of the manuscript. Support for instruments and deployment was provided to SIO by the Alaska Fisheries Science Center, National Marine Mammal Laboratory, through Joint Institute of Marine Observations Grant No. NA17RJ1231.

\section{REFERENCES}

ANONYMOUS. 1989. NOAA aids rescue of gray, beluga whales. Marine Fisheries Review 51(1):51.

BRAHAM, H.W. 1984. Distribution and migration. In: Jones, M.L., Swartz, S.L., and Leatherwood, S., eds. The gray whale, Eschrichtius robustus. San Diego, California: Academic Press. 249-266.

CHARIF, R.A., CLARK, C.W., and FRISTRUP, K.M. 2004. Raven 1.2 user's manual. Ithaca, New York: Cornell Laboratory of Ornithology.

CLARK, C.W., and ELLISON, W.T. 2000. Calibration and comparison of the acoustic location methods used during the spring migration of the bowhead whale, Balaena mysticetus, off Pt. Barrow, Alaska, 1984-1993. Journal of the Acoustical Society of America 107:3509-3517.

DAHLHEIM, M.E., FISHER, H.D., and SCHEMPP, J.D. 1984. Sound production by the gray whale and ambient noise levels in Laguna San Ignacio, Baja California Sur, Mexico. In: Jones, M.L., Swartz, S.L., and Leatherwood, S., eds. The gray whale, Eschrichtius robustus. San Diego, California: Academic Press. 511-541.

DUNHAM, J.S., and DUFFUS, D.A. 2001. Foraging patterns of gray whales in central Clayoquot Sound, British Columbia, Canada. Marine Ecology Progress Series 223:299-310.

EICKEN, H., SHAPIRO, L., and GAYLORD, A.G. 2006. Mapping and characterization of recurring spring leads and landfast ice in the Beaufort and Chukchi seas. AK-03-06, MMS 71707. Available from H. Eicken, Geophysical Institute, University of Alaska Fairbanks, Fairbanks, Alaska 99775-7320. 
GEORGE, J.C., ZEH, J., SUYDAM, R., and CLARK, C.W. 2004. Abundance and population trend (1978-2001) of western Arctic bowhead whales surveyed near Barrow, Alaska. Marine Mammal Science 20(4):755-773.

KIM, S.L., and OLIVER, J.S. 1989. Swarming benthic crustaceans in the Bering and Chukchi seas and their relation to geographic patterns in gray whale feeding. Canadian Journal of Zoology 67(6): $1531-1542$.

KO, D., ZEH, J.E., CLARK, C.W., ELLISON, W.T., KROGMAN, B.D., and SONNTAG, R.1986. Utilization of acoustic location data in determining a minimum number of spring-migrating bowhead whales unaccounted for by the ice-based visual census. Reports of the International Whaling Commission 36:325 - 338.

MELLINGER, D.K. 2002. ISHMAEL 1.0 user's guide. National Oceanic and Atmospheric Administration Technical Memorandum, OAR PMEL-120. Available from NOAA/Pacific Marine Environmental Laboratory, 7600 Sand Point Way NE, Seattle, Washington 98115. 26 p.

MOORE, S.E., and LJUNGBLAD, D.K. 1984. Gray whales in the Beaufort, Chukchi and Bering seas: Distribution and sound production. In: Jones, M.L., Swartz, S.L., and Leatherwood, S., eds. The gray whale, Eschrichtius robustus. San Diego, California: Academic Press. 543-559.

MOORE, S.E., BENNETT, J.C., and LJUNGBLAD, D.K. 1989. Use of passive acoustics in conjunction with aerial surveys to monitor the fall bowhead whale (Balaena mysticetus) migration. Reports of the International Whaling Commission 39:291 - 295.

MOORE, S.E., DeMASTER, D.P., and DAYTON, P.K. 2000. Cetacean habitat selection in the Alaskan Arctic during summer and autumn. Arctic 53(4):432-447.

MOORE, S.E., GREBMEIER, J.M., and DAVIES, J.R. 2003. Gray whale distribution relative to forage habitat in the northern
Bering Sea: Current conditions and retrospective summary. Canadian Journal of Zoology 81:734-742.

MOORE, S.E., WYNNE, K.M., CLEMENT-KINNEY, J., and GREBMEIER, J.M. 2007. Gray whale occurrence and forage southeast of Kodiak Island, Alaska. Marine Mammal Science 23(2):419-428.

NERINI, M. 1984. A review of gray whale feeding ecology. In: Jones, M.L., Swartz, S.L., and Leatherwood, S., eds. The gray whale, Eschrichtius robustus. San Diego, California: Academic Press. 423-450.

PERRYMAN, W.L., and LYNN, M.S. 2002. Evaluation of nutritive condition and reproductive status of migrating gray whales (Eschrichtius robustus) based on analysis of photogrammetric data. Journal of Cetacean Research and Management 4(2): $155-164$.

PERRYMAN, W.L., DONAHUE, M.A., PERKINS, P.C., and REILLY, S.B. 2002. Gray whale calf production 1994-2000: Are observed fluctuations related to changes in seasonal ice cover? Marine Mammal Science 18(1):121-144.

RUGH, D.J., and FRAKER, M.A. 1981. Gray whale (Eschrichtius robustus) sightings in eastern Beaufort Sea. Arctic 34(2): $186-187$.

RUGH, D.J., SHELDEN, K.E.W., and SHULMAN-JANIGER, A. 2001. Timing of the gray whale southbound migration. Journal of Cetacean Research and Management 3(1):31 -39.

RUGH, D.J., HOBBS, R.C., LERCZAK, J.A., and BREIWICK, J.M. 2005. Estimates of abundance of the eastern North Pacific stock of gray whales (Eschrichtius robustus) 1997 to 2002. Journal of Cetacean Research and Management 7(1):1-12.

WIGGINS, S. 2003. Autonomous Acoustic Recording Packages (ARPs) for long-term monitoring of whale sounds. Marine Technology Society Journal 37:13-22. 